\title{
Brain tissue oxygen reactivity: clinical implications and pathophysiology
}

\author{
Gurgen Harutyunyan ${ }^{1 *}$, Harutyun Mangoyan ${ }^{2}$ and Gagik Mkhoyan ${ }^{2}$ \\ 1 Department of Emergency Medicine, Hospital 9 De Octubre, Valencia, Spain \\ ${ }^{2}$ Department of Intensive Care, Erebuni Medical Center, Yerevan, Armenia \\ *Correspondence: varsenik@hotmail.es
}

Edited and reviewed by:

Suren Soghomonyan, The Ohio State University Wexner Medical Center, USA

Keywords: brain tissue oxygen reactivity, cerebral blood flow, blood buffers, brain metabolism, cerebral metabolism

\section{INTRODUCTION}

It is generally accepted that $\mathrm{PbO}_{2}$ reflects the balance between $\mathrm{O}_{2}$ delivery and consumption (Diringer et al., 2007; Diringer, 2008). However, implementation in the perioperative period of various ventilatory modes using high $\mathrm{FiO}_{2}$ leads to a dramatic and non-physiologic increase in $\mathrm{PbO}_{2}$ with approximating levels of 147 $\pm 36 \mathrm{mmHg}$ (McLeod et al., 2003). This phenomenon doesn't correlate with the extent of slight increase in arterial $\mathrm{O}_{2}$ content. At the same time, the jugular venous $\mathrm{PO}_{2}$ increases only slightly $(37-40 \mathrm{mmHg}$ ) (Forkner et al., 2007). Moreover, hyperoxia does not affect significantly the regional $\mathrm{CBF}$, and there is no improvement in cerebral metabolism with oxygen therapy (Magnoni et al., 2003; Diringer et al., 2007; Diringer, 2008; Xu et al., 2012).

The $\mathrm{PbO}_{2}$ increase is more pronounced in edematous (but not necrotized) brain tissues compared to normal areas (Meixensberger et al., 1993). Although, this can be considered a positive phenomenon, it masks the real state of rCBF and local oxidative metabolism. Recording of high $\mathrm{PbO}_{2}$ absolute values may create a false impression of safety and negatively impact the clinical decision making. Apparently, better indicators of the status of energy exchange in the brain tissue are needed for practical use in the perioperative and critical care settings.

\section{BRAIN TISSUE OXYGEN REACTIVITY: CLINICAL IMPLICATIONS}

Dynamic assessment of relative changes in brain oxygenation to monitor the brain functionality is a better approach compared to relying on a single parameter. With such monitoring, both the current status of brain tissue oxygenation and the functional reserve capabilities can be accomplished.

Brain tissue oxygen reactivity (BTOR) is the measure (in percents) of $\mathrm{PbO}_{2}$ changes relative to changes in $\mathrm{PaO}_{2}$ $\left(\Delta \mathrm{PbO}_{2} / \Delta \mathrm{PaO}_{2}\right)$ with oxygen inhalation (Johnston et al., 2003). The latter parameter can be easily adjusted to reach BTOR optimal values. The technique of measurement includes increasing the $\mathrm{FiO}_{2}$ up to 1.0 with simultaneous recording of the $\mathrm{PaO}_{2}$ and $\mathrm{PbO}_{2}$ values.

Literature reports indicate that high BTOR values within the first $24 \mathrm{~h}$ after TBI are considered an indicator of unfavorable outcome and negatively correlate with the Glasgow Outcome Score (van Santbrink et al., 1996; Menzel et al., 1999).

It is not mandatory to apply the maximal $\mathrm{FiO}_{2}$ of 1.0 to calculate the BTOR. Any other high inspired $\mathrm{O}_{2}$ levels can be applied that will produce significant $\mathrm{PbO}_{2}$ changes within $20 \mathrm{~min}$. Such a time period is considered the minimal required interval adequate for equilibration and meaningful assessment. During this short period, the respiration, regional metabolism and the $\mathrm{rCBF}$ are assumed to remain stable, and the calculated values of $\Delta \mathrm{PbO}_{2} / \Delta \mathrm{PaO}_{2}$ will indirectly characterize the $\mathrm{rCBF}$.

Low BTOR is considered a positive phenomenon even when the absolute $\mathrm{PbO}_{2}$ values decrease, unless regional hypoperfusion $(<20 \mathrm{ml} / 100 \mathrm{~g} / \mathrm{min}$ ) exists (Hlatky et al., 2008). Simultaneous elevations of $\mathrm{PbO}_{2}$ and $\Delta \mathrm{PbO}_{2} / \Delta \mathrm{PaO}_{2}$ values reflect the imbalance between the oxygen delivery and consumption.

Under normal cardio-respiratory conditions, when the right to left pulmonary shunting is negligible, the $\mathrm{FiO}_{2}$ is proportional to $\mathrm{PaO}_{2}$. On the other hand, $\mathrm{PbO}_{2}$ itself correlates with $\mathrm{PaO}_{2}$. Therefore, one can presume that $\mathrm{FiO}_{2}$ is proportional to $\mathrm{PbO}_{2}$. Taking this into account, the formula used to calculate the BTOR can be modified to evaluate the correlation between the changes in $\mathrm{PbO}_{2}$ and $\mathrm{FiO}_{2}$. This new parameter $\left(\Delta \mathrm{PbO}_{2} / \Delta \mathrm{FiO}_{2}\right)$ is considered an equivalent of BTOR and can be easily calculated. This is a simple and practical approach to BTOR assessment that can be readily used at bedside. Such an approach will allow for dynamic assessment of tissue oxygen reactivity.

\section{BTOR: PATHOPHYSIOLOGY}

In order to illustrate the importance of BTOR as an ultimate indicator of balance between the rCBF, oxygen delivery and consumption and justify the need for its monitoring, the hypothesis of hyperreactive, non-physiologic, luxurious $\mathrm{PbO}_{2}$ elevation is proposed.

We hypothesize that the significant increase of $\mathrm{PbO}_{2}$ with hyperoxia in the injured brain is explained by an excessive right shift of the oxyhemoglobin dissociation curve with resultant significant reduction in hemoglobin's affinity to oxygen molecules at the microcirculatory level. This is a result of a mismatch between the $\mathrm{rCBF}$ and existing cerebral metabolic rate of oxygen $\left(\mathrm{CMRO}_{2}\right)$, which leads to accumulation of $\mathrm{CO}_{2}$, converted by erythrocyte carboanhydrase into $\mathrm{HCO}_{3}^{-}$and $\mathrm{H}^{+}$ions (at a 1000 times faster rate compared to plasma and extracellular space). It is known that $\mathrm{CO}_{2}$ and $\mathrm{H}^{+}$, which are produced during the tissue metabolism, are heterotropic effectors of hemoglobin 
that enhance oxygen release (Berg et al., 2002). The latter ions bind to hemoglobin with release of oxygen. With decrease in $\mathrm{rCBF}$ and/or relative increase of $\mathrm{CMRO}_{2}$, hemoglobin gets saturated with protons and practically loses its affinity to oxygen in the microcirculatory bed.

The role of $\mathrm{CO}_{2}$-induced local increase of $\mathrm{PO}_{2}$ is particularly important in the brain tissue where, under normal conditions (glucose-dependant metabolism without chronic fasting), the respiratory quotient equals 1 and the $\mathrm{CO}_{2}$ production almost 1.25 times exceeds that of the other tissues.

According to the above mentioned considerations, the rCBF determines $\mathrm{PbO}_{2}$ values via two principal mechanisms: (a) as an oxygen delivery mechanism within the arterial compartment and (b) via a "non-physiologic" right shift of the oxyhemoglobin dissociation curve as a result of decreased removal rate of the flowdependent metabolites in the microcirculatory bed.

Many drugs and techniques used commonly during therapy of severe TBI, including manitol, sodium thiopenthal, ketorolac, nimodipine, intra-arterial papaverine, hypothermia, deep sedation, etc., can reduce the $\mathrm{PbO}_{2}$ in the damaged tissue (Steiner et al., 2001; Gupta et al., 2002; Stiefel et al., 2004, 2006; Sakowitz et al., 2007). On the other hand, the effects of medically induced augmentation of cerebral perfusion pressure on cerebral oxygenation are difficult to predict (Sahuquillo et al., 2000; Imberti et al., 2002; Le Roux and Oddo, 2013). In addition, Zygun et al. (2009) showed that even though transfusion of packed red blood cells in TBI patients may improve the brain tissue oxygenation, it won't have an appreciable effect on cerebral metabolism (Zygun et al., 2009). Thus, there is a complex interaction of multiple factors influencing the functional and metabolic activity of the injured brain including injury-related pathological mechanisms, drugs and methods used to manage these patients. Their overall effects are not straightforward and cannot be anticipated easily in an individual case. Apparently, Monitoring of $\mathrm{PbO}_{2}$ in these patients will not provide reliable feedback and may be misleading in some cases. It is not justified to treat the severe TBI patients relying only on the $\mathrm{PbO}_{2}$ as an indicator of adequacy of cerebral metabolism. Instead, dynamic oxygen reactivity should be routinely monitored as an indicator of overall brain tissue oxygenation and metabolism.

\section{CALCULATIONS}

Assuming CBF and $\mathrm{CMRO}_{2}$ stability during oxygen therapy and equivalence of $\mathrm{PbO}_{2}$ with capillary $\mathrm{PO}_{2}$, (Kett-White et al., 2002) we can modify the standard formula for calculation of arteriovenous difference in oxygen (Kett-White et al., 2002) to determine the changes in hemoglobin saturation in the capillary blood:

$$
\begin{gathered}
\mathrm{Sv} \cdot{ }_{\mathrm{a}} \mathrm{O}_{2}-\mathrm{Sv} \cdot{ }_{\mathrm{b}} \mathrm{O}_{2}=\left[\mathrm{Ct}_{\mathrm{a}} \mathrm{O}_{2}(\mathrm{a})-\mathrm{Ct}_{\mathrm{b}} \mathrm{O}_{2}(\mathrm{a})\right. \\
\left.-0.003 *\left(\mathrm{~Pb}_{\mathrm{a}} \mathrm{O}_{2}-\mathrm{Pb}_{\mathrm{b}} \mathrm{O}_{2}\right)\right] / 1.34 \mathrm{xHb}
\end{gathered}
$$

where $\mathrm{Sv}_{\cdot \mathrm{a}} \mathrm{O}_{2}$ and $\mathrm{Sv}_{\cdot \mathrm{b}} \mathrm{O}_{2}$ are oxygen saturation at distal microcirculatory level after and before inhalation of oxygen; $\mathrm{Ct}_{\mathrm{a}} \mathrm{O}_{2}$ (a) and $\mathrm{Ct}_{\mathrm{b}} \mathrm{O}_{2}(\mathrm{a})$ are arterial oxygen content values after and before initiating oxygen therapy; $\mathrm{Pb}_{\mathrm{a}} \mathrm{O}_{2}$ and $\mathrm{Pb}_{\mathrm{b}} \mathrm{O}_{2}$ are $\mathrm{PbO}_{2}$ values after and before starting inhalation of oxygen; and $\mathrm{Hb}$ is hemoglobin concentration in $\mathrm{g} / \mathrm{dL}$.

For example, if we increase $\mathrm{PbO}_{2}$ from $\mathrm{P}_{50}=35 \mathrm{mmHg}$ (if hemoglobin saturation is 0.5 or $50 \%$ ) to $100 \mathrm{mmHg}$ and assume a change in $\mathrm{CtO}_{2}$ (a) equal to 1 vol. \%, the hemoglobin saturation at distal microcirculatory level will change in the following way (assuming a hemoglobin concentration $12 \mathrm{~g} / \mathrm{dL}$ ):

$$
\begin{gathered}
\mathrm{Sv}_{\mathrm{a}} \mathrm{O}_{2}-\mathrm{Sv}_{\mathrm{b}} \mathrm{O}_{2}=[1-0.003 *(100-35)] \\
/ 1.34 \mathrm{x} 12=0.05 \text { or } 5 \%
\end{gathered}
$$

This means that the distal microcirculatory oxygen saturation under these arterial conditions $\left(\mathrm{PbO}_{2}=100 \mathrm{mmHg}\right)$ will only increase $50 \%+5 \%=55 \%$.

Calculations show the weak affinity of hemoglobin to oxygen under these conditions which results in allocation of additional oxygen amounts out of hemoglobin with creation of abnormally high $\mathrm{PbO}_{2}$ in injured brain tissue areas.

\section{CONCLUSIONS}

Monitoring of BTOR or its equivalent $\Delta \mathrm{PbO}_{2} / \Delta \mathrm{FiO}_{2}$ is indicated during the intensive therapy of TBI patients. Both indices reflect the actual status of cerebral oxidative metabolism and help to reduce the risk of management errors which are otherwise masked by high $\mathrm{FiO}_{2}$-induced "adequate" $\mathrm{PbO}_{2}$ absolute values.

Blood transfusions, controlled hyperventilation and restoration of the regional acid-base balance should be performed under the guidance of above mentioned indices.

Further studies will help to establish the role of BTOR and $\Delta \mathrm{PbO}_{2} / \Delta \mathrm{FiO}_{2}$ monitoring in assessment of metabolic changes and adaptations taking place in the injured brain during the acute phase of TBI.

\section{DISCLOSURE}

The authors did not receive any financial or other support related to this work.

\section{REFERENCES}

Berg, J. M., Tymoczko, J. L., and Stryer, L. (2002). Biochemistry, 5th Edn. New York, NY: W. H. Freeman. Section 10.2, Hemoglobin Transports Oxygen Efficiently by Binding Oxygen Cooperatively. Available online at: http://www. ncbi.nlm.nih.gov/books/NBK22596/

Diringer, M. N. (2008). Hyperoxia: good or bad for the injured brain? Curr. Opin. Crit. Care 14, 167-171. doi: 10.1097/MCC.0b013e3282f57552

Diringer, M. N., Aiyagari, V., Zazulia, A. R., Videen, T. O., and Powers, W. J. (2007). Effect of hyperoxia on cerebral metabolic rate for oxygen measured using positron emission tomography in patients with acute severe head injury. J. Neurosurg. 106, 526-529. doi: 10.3171/jns.2007.106.4.526

Forkner, I. F., Piantadosi, C. A., Scafetta, N., and Moon, R. E. (2007). Hyperoxia-induced tissue hypoxia: a danger? Anesthesiology 106, 1051-1055. doi: 10.1097/01.anes.0000265167.14383.44

Gupta, A. K., Al-Rawi, P. G., Hutchinson, P. J., and Kirkpatrick, P. J. (2002). Effect of hypothermia on brain tissue oxygenation in patients with severe head injury. Br. J. Anaesth. 88, 188-192. doi: 10.1093/bja/88.2.188

Hlatky, R., Valadka, A. B., Gopinath, S. P., and Robertson, C. S. (2008). Brain tissue oxygen tension response to induced hyperoxia reduced in hypoperfused brain. J. Neurosurg. 108, 53-58. doi: 10.3171/JNS/2008/108/01/0053

Imberti, R., Bellinzona, G., and Langer, M. (2002). Cerebral tissue $\mathrm{PO} 2$ and $\mathrm{SjvO} 2$ changes during moderate hyperventilation in patients with severe traumatic brain injury. J. Neurosurg. 96, 97-102. doi: 10.3171/jns.2002.96.1.0097

Johnston, A. J., Steiner, L. A., Gupta, A. K., and Menon, D. K. (2003). Cerebral oxygen vasoreactivity and cerebral tissue oxygen reactivity. $\mathrm{Br}$. J. Anaesth. 90, 774-786. doi: 10.1093/bja/aeg104

Kett-White, R., Hutchinson, P. J., Czosnyka, M., Boniface, S., Pickard, J. D., and Kirkpatrick, P. J. (2002). Multi-modal monitoring of acute brain injury. Adv. Tech. Stand. Neurosurg. 27, 87-134. doi: 10.1007/978-3-7091-6174-6_3 
Le Roux, P. D., and Oddo, M. (2013). Parenchymal brain oxygen monitoring in the neurocritical care unit. Neurosurg. Clin. N. Am. 24, 427-439. doi: 10.1016/j.nec.2013.03.001

Magnoni, S., Ghisoni, L., Locatelli, M., Caimi, M., Colombo, A., Valeriani, V., et al. (2003). Lack of improvement in cerebral metabolism after hyperoxia in severe head injury: a microdialysis study. J. Neurosurg. 98, 952-958. doi: 10.3171/jns.2003.98.5.0952

McLeod, A. D., Igielman, F., Elwell, C., Cope, M., and Smith, M. (2003). Measuring cerebral oxygenation during normobaric hyperoxia: a comparison of tissue microprobes, near-infrared spectroscopy, and jugular venous oximetry in head injury. Anesth. Analg. 97, 851-856. doi: 10.1213/01.ANE.0000072541.57132.BA

Meixensberger, J., Dings, J., Kuhnigk, H., and Roosen, K. (1993). Studies of tissue PO2 in normal and pathological human brain cortex. Acta Neurochir. Suppl. (Wien) 59, 58-63.

Menzel, M., Doppenberg, E. M., Zauner, A., Soukup, J., Reinert, M. M., Clausen, T., et al. (1999). Cerebral oxygenation in patients after severe head injury: monitoring and effects of arterial hyperoxia on cerebral blood flow, metabolism and intracranial pressure. J. Neurosurg. Anesthesiol. 11, 240-251. doi: 10.1097/00008506-19991000000003

Sahuquillo, J., Amoros, S., Santos, A., Poca, M. A., Panzardo, H., Domínguez, L., et al. (2000). Does an increase in cerebral perfusion pressure always mean a better oxygenated brain? A study in head-injured patients. Acta Neurochir. Suppl. 76, 457-462.

Sakowitz, O. W., Stover, J. F., Sarrafzadeh, A. S., Unterberg, A. W., and Kiening, K. L. (2007). Effects of mannitol bolus administration on intracranial pressure, cerebral extracellular metabolites, and tissue oxygenation in severely head-injured patients. J. Trauma 62, 292-298. doi: 10.1097/01.ta.0000203560.03937.2d

Steiner, T., Pilz, J., Schellinger, P., Wirtz, R., Friederichs, V., Aschoff, A., et al. (2001). Multimodal online monitoring in middle cerebral artery territory stroke. Stroke 32, 2500-2506. doi: 10.1161/hs1101.097400

Stiefel, M. F., Heuer, G. G., Abrahams, J. M., Bloom, S., Smith, M. J., Maloney-Wilensky, E., et al. (2004). The effect of nimodipine on cerebral oxygenation in patients with poor-grade subarachnoid hemorrhage. J. Neurosurg. 101, 594-599. doi: 10.3171/jns.2004.101.4.0594

Stiefel, M. F., Spiotta, A. M., Udoetuk, J. D., MaloneyWilensky, E., Weigele, J. B., Hurst, R. W., et al. (2006). Intra-arterial papaverine used to treat cerebral vasospasm reduces brain oxygen. Neurocrit. Care 4, 113-118. doi: 10.1385/NCC:4:2:113

van Santbrink, H., Maas, A. I., and Avezaat, C. J. (1996). Continuous monitoring of partial pressure of brain tissue oxygen in patients with severe head injury. Neurosurgery 38, 21-31. doi: 10.1097/00006123-199601000-00007

Xu, F., Liu, P., Pascual, J. M., Xiao, G., and Lu, H. (2012). Effect of hypoxia and hyperoxia on cerebral blood flow, blood oxygenation, and oxidative metabolism. J. Cereb. Blood Flow Metab. 32, 1909-1918. doi: 10.1038/jcbfm.2012.93

Zygun, D. A., Nortje, J., Hutchinson, P. J., Timofeev, I., Menon, D. K., and Gupta, A. K. (2009). The effect of red blood cell transfusion on cerebral oxygenation and metabolism after severe traumatic brain injury. Crit. Care Med. 37, 1074-1078. doi: 10.1097/CCM.0b013e318194ad22

Conflict of Interest Statement: The authors declare that the research was conducted in the absence of any commercial or financial relationships that could be construed as a potential conflict of interest.

Received: 29 March 2014; accepted: 17 April 2014; published online: 20 May 2014.

Citation: Harutyunyan G, Mangoyan $H$ and Mkhoyan $G$ (2014) Brain tissue oxygen reactivity: clinical implications and pathophysiology. Front. Pharmacol. 5:100. doi: $10.3389 /$ fphar.2014.00100

This article was submitted to Cardiovascular and Smooth Muscle Pharmacology, a section of the journal Frontiers in Pharmacology.

Copyright (C) 2014 Harutyunyan, Mangoyan and Mkhoyan. This is an open-access article distributed under the terms of the Creative Commons Attribution License (CC BY). The use, distribution or reproduction in other forums is permitted, provided the original author(s) or licensor are credited and that the original publication in this journal is cited, in accordance with accepted academic practice. No use, distribution or reproduction is permitted which does not comply with these terms. 